\title{
IMPLEMENTASI METODE WEIGHTED PRODUCT DALAM SISTEM PENUNJANG KEPUTUSAN PEMBUANGAN MATERIAL NOT GOOD (NG) PRODUKSI
}

\author{
Mujahidin Mujahidin ${ }^{1}$, Arif Budimansyah Purba², Tresa Agustian ${ }^{3}$ \\ 1'mujahidin607@gmail.com, 2arifbudimansyahpurba@gmail.com, 3tresaagustian1976@gmail.com \\ STMIK Kharisma Karawang
}

\begin{abstract}
Abstrak
Material Not Good adalah material produk yang kondisinya rusak atau tidak memenuhi ukuran mutu yang telah ditentukan, oleh karenanya dalam menangani material NG ini bisa di tentukan material apa saja yang harus di buang dan material yang harus di repair. Dalam material tersebut ada beberapa kriteria yang bisa menjadi tolak ukur untuk menentukan setatus material NG, langsung di buang ke limbah produksi atau tidak. Untuk menentukan material NG produksi bisa di lakukan dengan menggunakan sistem penunjang keputusan metode Weighted Product. Penentuan rangking bisa di lakukan dengan melihat dari jumlah kriteria-kriteria pada alternatif material NG produksi dengan melakukan perhitungan Weighted Product dapat membantu dalam pengambilan keputusan dalam pembuangan material NG dan hanya memilih 1 material yang akan di buang ke limbah produksi yang statusnya tidak bisa di repair kembali dan hasil akhir metode Weighted Product memiliki nilai akhir yang berubah sesusai banyaknya alternatif.
\end{abstract}

Kata Kunci: Weighted Product, Material Not Good (NG), Weighted product, Sistem Penunjang Keputusan, SDLC Waterfall.

\section{Abstract}

Bad Material is a product whose condition is Damaged or Not In accordance with a predetermined size, in the matter of this NG material can be determined what materials must be disposed of and what materials must be repaired. In the material there are several criteria that can be used as a yardstick to determine whether the NG material is directly discharged into production waste or not. To determine the NG material production can be done by using a weighted product support system. Ranking determination can be done by looking at the number of criteria in the alternative NG production by calculating weighted products can help in making decisions in the disposal of NG material and only choose one material to be disposed of into production waste whose status cannot be repaired again and the final result of the Weighted Product method has a final value that changes according to the number of alternatives.

Keywords: Weighted Product, Material Not Good (NG), Weighted product, Decision Support System, SDLC Waterfall

\section{Pendahuluan}

Dalam sebuah perusahaan kelancaran produksi sangatlah penting karena merupakan sebuah parameter untuk kemajuan atau kemunduran sebuah perusahaan. Produksi adalah suatu kegiatan untuk menciptakan dan menambah kegunaan suatu barang dan jasa [1]. Pada saat menjalankan produksi tidak semua yang di hasilkan dari proses produksi tersebut berjalan lancar berupa barang yang bagus, akan tetapi ada barang tidak bagus Not Good (NG) yang tidak bisa di pakai untuk pengiriman ke customer. Barang NG tidak bisa di hindari karena akan ada dalam suatu produksi yang di sebabkan oleh beberapa faktor, mulai dari mesin, material bahan baku, ataupun dari karyawan yang melakukan kesalahan dalam proses produksi. Jika barang NG tersebut sampai terkirim ke customer maka akan berdampak buruk yaitu akan terjadi claim customer. Penyebab terjadinya produk rusak ada dua yaitu produk rusak karena kagiatan normal perusahaan atau produk rusak normal dan produk rusak karena kesalahan atau produk rusak abnormal [2].

PT. FCC Indonesia adalah perusahaan otomotif yang memproduksi komponen sparepart motor yaitu kopling. Dalam melakukan produksinya memiliki komponen-komponen yang harus di rakit untuk di jadikan satu set kopling, semua komponen material itu di rakit di assembling line pulley assy. Namun demikian dari material yang di rakit tersebut ada material yang kurang jelas statusnya yang biasanya di simpan di box kuning, apakah material tersebut NG secara keseluruhan tidak bisa di pakai yang akhirnya harus di buang ke limbah produksi atau bisa dipakai kembali untuk di repair. Dengan adanya permasalahan yang terjadi di atas mengenai status material NG dan harus benar-benar di 
ILKOM Jurnal Ilmiah Volume 11 Nomor 1 April 2019

Terakreditasi peringkat 3 SK. No. 28/E/KPT/2019

tangani dengan baik juga. Maka dari itu barang tersebut bagaimana cara untuk menentukan bahwa material itu bisa di pastikan NG di sini masih terkendala menentukan apakah material tersebut mau di buang ke limbah ataupun bisa di pakai kembali untuk di repair. Sebagai perusahaan yang telah menggunakan sistem berbasis komputer dalam kegiatan usahanya maka bisa di manfaatkan untuk menjalankan sistem pendukung keputusan menentukan apakah material NG tersebut di buang ke limbah atau bisa dipakai kembali setelah repair, dengan cara diperoleh data-data dari kriteria yang ada pada barang tersebut dan di lakukan oleh pimpinan produksi. Dalam menentukan material tersebut bisa di lihat dari beberapa kriteria mulai dari kebersihan produk, luka di bagian material (dakon), pengukuran keseimbangan (balance), runnout material dan jumlah bor.

Pada penelitian ini, metode yang digunakan adalah metode Weighted Product (WP) karena berdasarkan beberapa penelitian sebelumnya bahwa metode WP bisa di pakai untuk membantu dalam mendukung keputusan masalah seperti diantaranya dapat memberikan solusi terhadap pemilihan motor penelitian di lakukan oleh Rani [3], Metode WP pemilihan laptop yang di lakukan oleh Nuraifah [4], Metode WP seleksi calon karyawan oleh Fauziah [5], Metode WP pemilihan mahasiswa terbaik oleh Cahyono [6]. Dari beberapa penelitian yang sudah dilakukan bahwa metode WP dalam sistem pendukung keputusan sangat baik dan layak di gunakan. Dalam merancang sistem penunjang keputusan ini digunakan metode pengembangan sistem adalah metode Waterfall dengan System Development Life Cycle (SDLC) dari Satzinger. SDLC adalah suatu metodologi pengembangan perangkat lunak yang mengusulkan pendekatan kepada perangkat lunak sistematik dan sekuensial yang mulai pada Project planning phase, Analysis phase, Design phase, Implementation phase dan Support phase [7].

\section{Metode}

\subsection{Metode Pengembangan Sistem}

Metode perancangan sistem yang digunakan dalam penelitian ini yaitu SDLC (System Development Life Cycle) Waterfall yang meliputi beberapa tahap yaitu project planing phase, analysis phase, design phase, implementation phase, dan support phase seperti pada gambar 1.

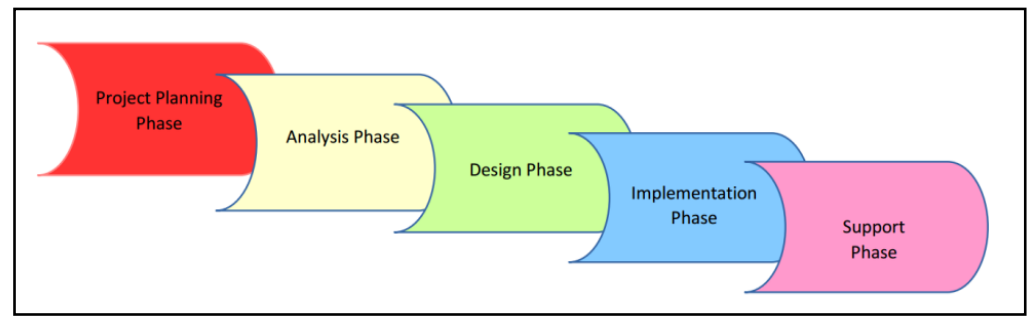

Gambar 1. The Waterfall Approach to The SDLC

\subsection{Bahan Penelitian}

Bahan penelitian yang akan digunakan dalam penelitian ini yaitu seluruh data yang berkaitan dengan material NG produksi seperti jenis model part NG, kriteria-kriteria yang ada pada material NG, laporan barang yang rusakatau NG di produksi.

\subsection{Alat Penelitian}

Alat yang digunakan dalam penelitian ini meliputi perangkat keras dan perangkat lunak dapat dilihat pada tabel 1 dan tabel 2 .

Tabel 1. Rincian Perangkat Keras Yang Digunakan

\begin{tabular}{cll}
\hline No. & Perangkat Keras & Spesifikasi \\
\hline 1. & Laptop (Sistem & $\begin{array}{l}\text { Suatu alat yang terdiri atas suatu perngkat yang memiliki papan tombol } \\
\text { (Keyboard), layar tampilan, dan microprocessor denga spesifikasi } \\
\text { processor CPU Intel Core i3; memory 2048 mb RAM. }\end{array}$ \\
Komputer) & $\begin{array}{l}\text { Alat yang digunakan untuk mencetak tampilan monitor ke kertas dan } \\
\text { informasi yang dicetak dapat berupa teks dan gambar. }\end{array}$ \\
\hline
\end{tabular}

Tabel 2. Rincian Perangkat Lunak Yang Digunakan 
ILKOM Jurnal IImiah Volume 11 Nomor 1 April 2019

Terakreditasi peringkat 3 SK. No. 28/E/KPT/2019

\begin{tabular}{cll}
\hline No. & Perangkat Keras & Spesifikasi \\
\hline 1. & PHP & Bahasa pemrograman yang digunakan. \\
2. & Apache2 & Web server open source. \\
3. & MySQL & Database management system. \\
4. & Geany & Editing kode program atau menulis kode program. \\
5. & Web Browser & $\begin{array}{l}\text { Program atau software yang di gunakan untuk menjelajahi web, } \\
\text { menampilkan dan berinteraksi dengan dokumen-dokumen yang di } \\
\end{array}$ \\
\hline
\end{tabular}

\section{Hasil dan Pembahasan}

\subsection{Project Planning Phase}

Tahap pertama yang dilakukan adalah tahap perencanaan atau project planning phase untuk menjelaskan kegiatan-kegiatan yang akan dilakukan dapat dilihat pada tabel 3.

Tabel 3. Project Planing Phase

\begin{tabular}{|c|c|c|}
\hline No. & Tahapan & Hasil \\
\hline 1. & Identifikasi masalah & $\begin{array}{l}\text { 1. Bagaimana proses menentukan pembuangan material NG } \\
\text { produksi dengan kriteria-kriteria yang menjadi } \\
\text { pertimbangan kualitas material. } \\
\text { 2. Bagaimana menerpakan metode WP pada sistem } \\
\text { pendukung keputusan pembuangan material NG produksi. } \\
\text { 3. Bagaimana merancang sistem pendukung keputusan } \\
\text { pembuangan material NG produksi menggunakan SDLC } \\
\text { Waterfall sebagai metode pengembangnya. }\end{array}$ \\
\hline 2. & Pengumpulan data & $\begin{array}{l}\text { Data yang didapat adalah dari bagian produksi section pulley } \\
\text { assy di antaranya data produk yang belum jelas statusnya } \\
\text { layak untuk digunakan atau tidak, yang berada di form produk } \\
\text { NG. }\end{array}$ \\
\hline 3 & Menganalisis teori & $\begin{array}{l}\text { 1. Dapat melihat dan menentukan alternatif yang paling } \\
\text { optimal. } \\
\text { 2. Dapat membuat perangkingan dari alternatif yang ada. } \\
\text { 3. Dapat mengimplemtasikan sistem penunjang keputusan } \\
\text { menggunakan metode WP. }\end{array}$ \\
\hline 4. & Pembuatan Jadwal & $\begin{array}{l}\text { Membuat rencana kerja tentang penelitian ini dengan } \\
\text { menghitung waktu yang diperlukan dari awal proyek sampai } \\
\text { tahap implementasi dan pengujian. }\end{array}$ \\
\hline 5. & $\begin{array}{l}\text { Mengidentifikasi } \\
\text { kebutuhan }\end{array}$ & $\begin{array}{l}\text { Menentukan tools yang akan digunakan untuk sistem ini baik } \\
\text { dari hardware maupun software. }\end{array}$ \\
\hline
\end{tabular}

\subsection{Analysis Phase}

Hasil dari analisis untuk menentukan pembuangan material NG produksi menggunakan metode weighted product berdasarkan tahapan-tahapan yang ada pada proses pengambilan keputusan, yaitu terdiri dari fase intelegensi, fase desain, fase pilihan dan fase implementasi, hasil implementasi yang berhasil adalah terpecahkannya masalah dan apabila gagal maka harus kembali ke fase sebelumnya.

\section{a. Penentuan Nilai Bobot W (Kriteria)}

Langkah awal yang harus dilakukan dalam menggunakan metode WP untuk menentukan untuk pembuangan material NG produksi adalah memberikan nilai setiap alternatif pada setiap kriteria yang sudah ditentukan. Dari masing-masing kriteria tersebut akan ditentukan bobotnya.

Terdapat 5 kriteria dalam menentukan pembuangan material NG produksi yaitu :

1. Pengukuran nilai keseimbangan material atau balance;

2. Kebersihan produk;

3. Luka di bagian material (dakon);

4. Pengukuran run out material;

5. Jumlah bor di material. 
ILKOM Jurnal Ilmiah Volume 11 Nomor 1 April 2019

Terakreditasi peringkat 3 SK. No. 28/E/KPT/2019

Berikut ini tabel 4, tabel 5, tabel 6, tabel 7, tabel 8 dan tabel 9 merupakan tabel pemberian bobot nilai pada setiap kriteria. Pada tabel 6 berisi prioritas bobot pada setiap kriteria yang ada.

Tabel 4. Kriteria Pengukuran Nilai Keseimbangan Material atau Balance (C1)

\begin{tabular}{|c|c|c|c|}
\hline \multicolumn{3}{|c|}{ NILAI } & BOBOT \\
\hline 0,00 & $-\quad 2,80$ & (Sangat Baik) & 1,00 \\
\hline 2,80 & - 6,00 & (Baik) & 0,75 \\
\hline 6,10 & - 8,50 & (Kurang) & 0,50 \\
\hline 8,50 & - 15,00 & (Buruk) & 0,25 \\
\hline
\end{tabular}

Tabel 6. Luka dibagian Material/Dako (C3)

\begin{tabular}{cc}
\hline NILAI & BOBOT \\
\hline Sangat Baik & 1,00 \\
Baik & 0,75 \\
Kurang & 0,50 \\
Buruk & 0,25 \\
\hline
\end{tabular}

Tabel 8. Kriteria Jumlah Bor di Material (C5)

\begin{tabular}{|c|c|c|}
\hline \multicolumn{2}{|c|}{ NILAI } & ВОВОТ \\
\hline Sangat Baik & $0,1-0,5$ & 1,00 \\
\hline Baik & $0,6-0,9$ & 0,75 \\
\hline Kurang & $0,10-0,20$ & 0,50 \\
\hline Buruk & $0,21-0,50$ & 0,25 \\
\hline
\end{tabular}

Tabel 5. Kriteria Kebersihan Product (C2)

\begin{tabular}{cc}
\hline NILAI & BOBOT \\
\hline Sangat Baik & 1,00 \\
Baik & 0,75 \\
Kurang & 0,50 \\
Buruk & 0,25 \\
\hline
\end{tabular}

Tabel 7. Kriteria Pengukuran Run Out Material (C4)

\begin{tabular}{llc}
\hline \multicolumn{2}{c}{ NILAI } & BOBOT \\
\hline Sangat Baik & $0,1-0,5$ & 1,00 \\
Baik & $0,6-0,9$ & 0,75 \\
Kurang & $0,10-0,20$ & 0,50 \\
Buruk & $0,21>=$ & 0,25 \\
\hline
\end{tabular}

Tabel 9. Nilai Prioritas Bobot Setiap Kriteria (W Init $)$

\begin{tabular}{cc}
\hline NILAI & BOBOT \\
\hline C1 & 30 \\
C2 & 20 \\
C3 & 15 \\
C4 & 10 \\
C5 & 25 \\
\hline
\end{tabular}

Langkah selanjutnya adalah menghitung nilai perbaikan bobot $\left(\mathrm{W}_{\mathrm{j}}\right)$ berdasarkan nilai prioritas bobot setiap kriteria $\left(W_{-}\right.$Init $\left.t_{j}\right)$ yang sudah ditentukan. Cara menghitung nilai perbaikan bobot $\left(W_{j}\right)$ terdapat pada persamaan (1)-(6) :

$$
\begin{aligned}
& j=\frac{W_{l n i t} j}{\sum_{j=1}^{n} W_{l n i t} j} \\
& W 1(\text { nilaibalance })=\frac{30}{30+20+15+10+25}=0,3 \\
& W 2(\text { Kebersihanproduk })=\frac{20}{30+20+15+10+25}=0,2 \\
& W 3(\text { lukadimaterial } / \text { dakon })=\frac{15}{30+20+15+10+25}=0,15 \\
& W 4(\text { PengukuranRunout })=\frac{10}{30+20+15+10+25}=0,1 \\
& W 5(\text { Bordimaterial })=\frac{25}{30+20+15+10+25}=0,25
\end{aligned}
$$

\section{b. Membuat Tabel Bobot Kriteria}


ILKOM Jurnal Ilmiah Volume 11 Nomor 1 April 2019

Terakreditasi peringkat 3 SK. No. 28/E/KPT/2019

Setelah menentukan nilai bobot $\mathrm{W}$, langkah selanjutnya adalah membuat tabel bobot kriteria material NG yang akan di buang ke limbah produksi yang ditunjukan pada tabel. Terdapat 5 Material NG yang akan siap di buang ke limbah produksi, dimana akan dipilih 1 material yang terlebih dahulu akan di buang ke limbah produksi. Data material NG yang di peroleh seperti pada tabel 10.

Tabel 10. Data Material NG

\begin{tabular}{clccccc}
\hline \multirow{2}{*}{ NO. } & \multirow{2}{*}{ NAMA MATERIAL NG } & \multicolumn{6}{c}{ KRITERIA } \\
\cline { 3 - 7 } & C1 & C2 & C3 & C4 & C5 \\
\hline 1. & Housing 2 DP Yamaha & SB & B & B & K & B \\
2. & Housing 2 PH-30 Yamaha & $\mathrm{B}$ & $\mathrm{Br}$ & $\mathrm{SB}$ & $\mathrm{B}$ & $\mathrm{K}$ \\
3. & Outer K81A Honda & $\mathrm{SB}$ & $\mathrm{B}$ & $\mathrm{B}$ & $\mathrm{SB}$ & $\mathrm{B}$ \\
4. & Outer KWN Honda & $\mathrm{B}$ & $\mathrm{K}$ & $\mathrm{Br}$ & $\mathrm{B}$ & $\mathrm{B}$ \\
5. & Outer XE314 Suzuki & $\mathrm{B}$ & $\mathrm{SB}$ & $\mathrm{B}$ & $\mathrm{B}$ & $\mathrm{SB}$ \\
\hline
\end{tabular}

Dimana :
SB :
$\mathrm{B} \quad:$ Sangat Baik
$\mathrm{K} \quad:$ Kaik
$\mathrm{Br}:$ Kurang
$\mathrm{C} 1 \quad:$ Nuruk
$\mathrm{C} 2 \quad:$ Kelai Balance
$\mathrm{C} 3 \quad:$ Lukersihan Produk
$\mathrm{C} 4 \quad:$ Pengukuran Run Out
$\mathrm{C} 5 \mathrm{:}$ Jumlah Bor di Material

Karena data yang didapat berupa data diskrit, maka ubah data diskrit menjadi data kontinu seperti pada tabel 11.

Tabel 11. Data Material NG

\begin{tabular}{clccccc}
\hline \multirow{2}{*}{ NO. } & \multirow{2}{*}{ NAMA MATERIAL NG } & \multicolumn{7}{c}{ KRITERIA } \\
\cline { 3 - 7 } & & C1 & C2 & C3 & C4 & C5 \\
\hline 1. & Housing 2 DP Yamaha & 1 & 0,75 & 0,75 & 0,5 & 0,75 \\
2. & Housing 2 PH-30 Yamaha & 0,75 & 0,25 & 1 & 0,75 & 0,5 \\
3. & Outer K81A Honda & 1 & 0,75 & 0,75 & 1 & 0,75 \\
4. & Outer KWN Honda & 0,75 & 0,5 & 0,25 & 0,75 & 0,75 \\
5. & Outer XE314 Suzuki & 0,75 & 1 & 0,75 & 0,75 & 1 \\
\hline
\end{tabular}

\section{c. Penentuan Nilai Vektor $\mathbf{S i}$}

Menghitung vektor $\mathrm{Si}_{\mathrm{i}}$, dimana data yang ada akan dikalikan tetapi sebelumnya dilakukan pemangkatan dengan bobot dari masing-masing kriteria.

$$
\begin{array}{ll}
\mathrm{S}_{1}(\text { Housing 2DP Yamaha) } & =1^{(0,3)} \times 0,75^{(0,2)} \times 0,75^{(0,15)} \times 0,5^{(0,1)} \times 0,75^{(0,25)} \\
\mathrm{S}_{1} \text { (Housing 2DP Yamaha) } & =1 \times 0,944 \times 0,957 \times 0,933 \times 0,930 \\
\mathrm{~S}_{1}(\text { Housing 2DP Yamaha) } & =0,783 \\
& \\
\mathrm{~S}_{2}(\text { Housing 2PH-30 Yamaha) } & =0,75^{(0,3)} \times 0,25^{(0,2)} \times 1^{(0,15)} \times 0,75^{(0,1)} \times 0,5^{(0,25)} \\
\mathrm{S}_{2}(\text { Housing 2PH-30 Yamaha) } & =0,917 \times 0,757 \times 1 \times 0,971 \times 0,840 \\
\mathrm{~S}_{2}(\text { Housing 2PH-30 Yamaha) } & =0,566^{\circ} \\
\mathrm{S}_{3}(\text { Outer K81A Honda) } & =1^{(0,3)} \times 0,75^{(0,2)} \times 0,75^{(0,15)} \times 1^{(0,1)} \times 0,75^{(0,25)} \\
\mathrm{S}_{3}(\text { Outer K81A Honda) } & =1 \times 0,944 \times 0,957 \times 1 \times 0,930 \\
\mathrm{~S}_{3}(\text { Outer K81A Honda) } & =0,840 \\
\mathrm{~S}_{4}(\text { Outer KWN Honda) } & =0,75^{(0,3)} \times 0,5^{(0,2)} \times 0,25^{(0,15)} \times 0,75^{(0,1)} \times 0,75^{(0,25)} \\
\mathrm{S}_{4}(\text { Outer KWN Honda) } & =0,917 \times 0,870 \times 0,812 \times 0,971 \times 0,930 \\
\mathrm{~S}_{4}(\text { Outer KWN Honda) } & =0,584 \\
\mathrm{~S}_{5}(\text { Outer XE314 Suzuki) } & =0,75^{(0,3)} \times 1^{(0,2)} \times 0,75^{(0,15)} \times 0,75^{(0,1)} \times 1^{(0,25)} \\
\mathrm{S}_{5}(\text { Outer XE314 Suzuki) } & =0,917 \times 1 \times 0,957 \times 0,971 \times 1 \\
\mathrm{~S}_{5}(\text { Outer XE314 Suzuki) } & =0,852
\end{array}
$$


ILKOM Jurnal Ilmiah Volume 11 Nomor 1 April 2019

Terakreditasi peringkat 3 SK. No. 28/E/KPT/2019

Menghitung vektor $\mathrm{Vi}_{\mathrm{i}}$ dengan cara membagi hasil masing-masing vektor $\mathrm{Si}$ dengan jumlah seluruh $\mathrm{Si}$. Cara menghitung vektor Vi seperti pada persamaan (7)-(13) :

$$
\begin{aligned}
& V i=\frac{S i}{\sum_{j=1}^{m} S i} \\
& \Sigma V i=0,783+0,566+0,840+0,584+0,852=3,625 \\
& V 1(\text { Housing } 2 \text { DPYamaha })=\frac{0,783}{3,625}=0,216 \\
& V 2(\text { Housing } 2 \text { PH30Yamaha })=\frac{0,566}{3,625}=0,156 \\
& V 3(\text { OuterK } 81 \text { AHonda })=\frac{0,840}{3,625}=0,231 \\
& V 4(\text { OuterKWNHonda })=\frac{0,584}{3,625}=0,161 \\
& V=5(\text { OuterXE314Suzuki })=\frac{0,852}{3,625}=0,235
\end{aligned}
$$

Semua hasil perhitungan vektor Vi dimasukkan kedalam table 12.

Tabel 12. Hasil $V_{i}$

\begin{tabular}{clc}
\hline NO. & \multicolumn{1}{c}{ Vi } & HASIL \\
\hline 1. & V1 (Housing 2DP Yamaha) & 0,216 \\
2. & V2 (Housing 2PH30 Yamaha) & 0,156 \\
3. & V3 (Outer K81A Honda) & 0,231 \\
4. & V4 (Outer KWN Honda) & 0,161 \\
5. & V5 (Outer XE314 Suzuki) & 0,235 \\
\hline
\end{tabular}

\section{e. Hasil Akhir}

Menghitung vektor $\mathrm{Si}$, dimana data yang ada akan dikalikan tetapi sebelumnya dilakukan pemangkatan dengan bobot dari masing-masing kriteria dapat dilihat pada tabel 13.

Tabel 13. Sorting Hasil $\mathrm{V}_{\mathrm{i}}$

\begin{tabular}{clc}
\hline NO. & \multicolumn{1}{c}{$\mathbf{V i}_{\mathbf{i}}$} & HASIL \\
\hline 1. & V5 (Outer XE314 Suzuki) & 0,235 \\
2. & V3 (Outer K81A Honda) & 0,231 \\
3. & V1 (Housing 2DP Yamaha) & 0,216 \\
4. & V4 (Outer KWN Honda) & 0,161 \\
5. & V2 (Housing 2PH30 Yamaha) & 0,156 \\
\hline
\end{tabular}

Karena dalam pembuangan NG material kita akan hanya memilih satu material yang akan di buang ke limbah produksi itu NG yang statusnya tidak bisa di repair kembali maka sistem menampilkan hasilnya dapat dilihat pada tabel 14.

Tabel 14. Sorting Hasil $\mathrm{V}_{\mathrm{i}}$ 
ILKOM Jurnal Ilmiah Volume 11 Nomor 1 April 2019

Terakreditasi peringkat 3 SK. No. 28/E/KPT/2019

\begin{tabular}{ccc}
\hline NO. & Vi & HASIL \\
\hline 1. & V5 (Outer XE314 Suzuki) & 0,235 \\
\hline
\end{tabular}

Sehingga dari hasil pengambilan keputusan ini adalah V5 yaitu Outer XE314 Suzuki.

1) System Activities

a. Actor Description

Aktor pada aplikasi ini terdiri dari satu aktor yaitu Leader pulley assy.

b. Use Case Diagram lihat gambar 2.

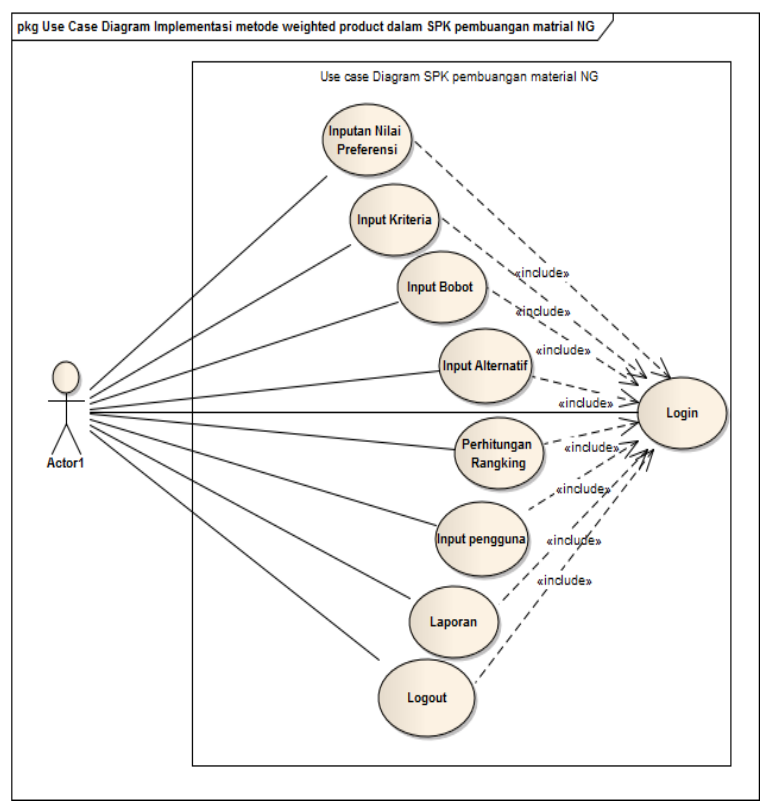

Gambar 2. Use Case Diagram

3) Squence Diagram lihat gambar 4.

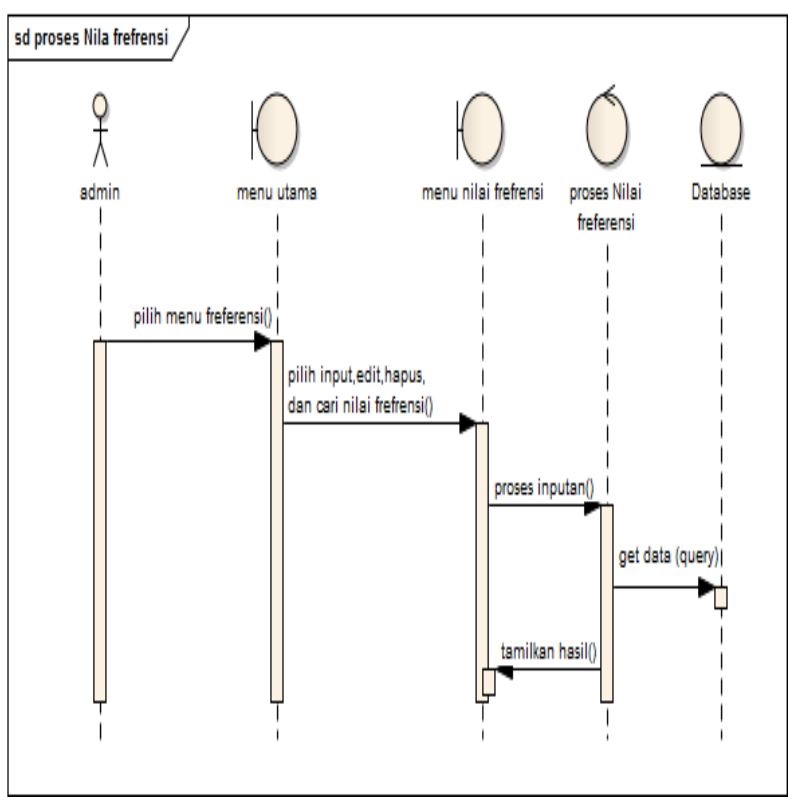

Gambar 4. Squence Diagram
2) Class Diagram lihat gambar 3.

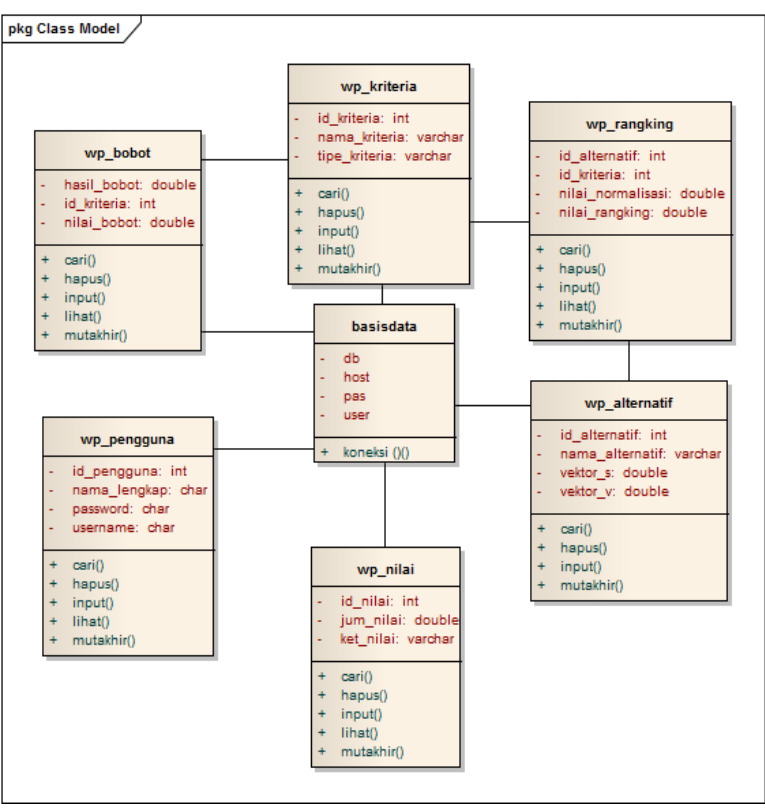

Gambar 3. Class Diagram

4) Activity Diagram lihat gambar 5 .

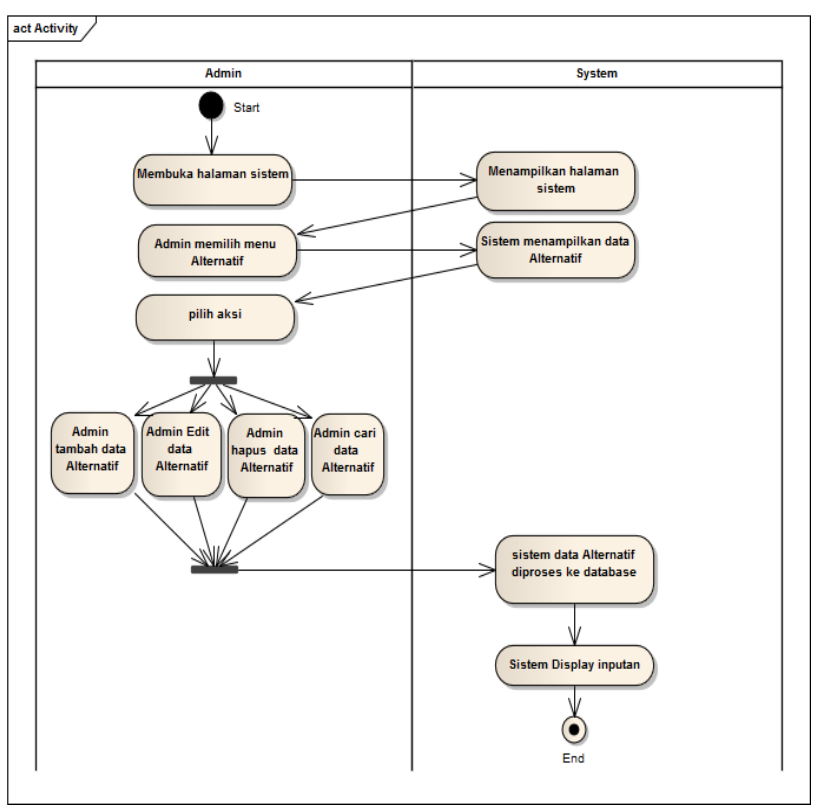

Gambar 5. Activity Diagram

\subsection{Design Phase}


ILKOM Jurnal IImiah Volume 11 Nomor 1 April 2019

Terakreditasi peringkat 3 SK. No. 28/E/KPT/2019

Desain Antar Muka dapat dlihat gambar 6.

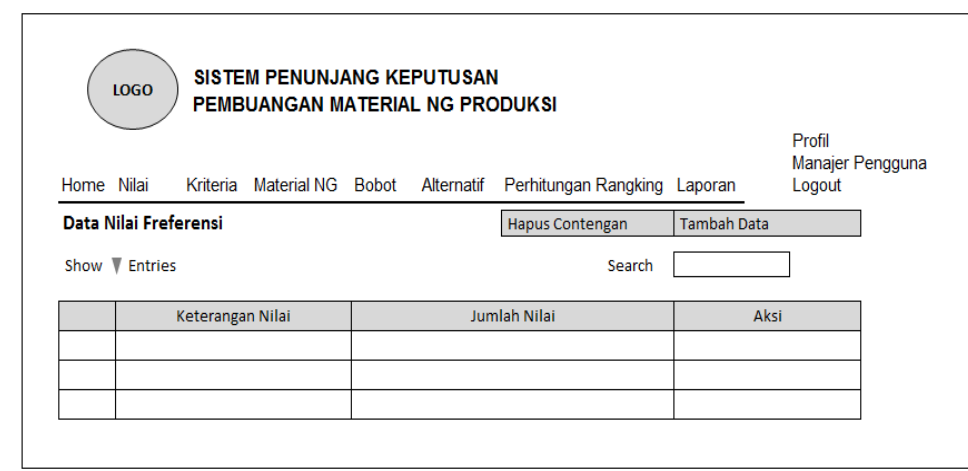

Gambar 6. Desain Antar Muka Data Nilai Freferensi

\subsection{Implementasi Phase}

Input Nilai untuk Perhitungan Rangking dapat di lihat gambar 7.

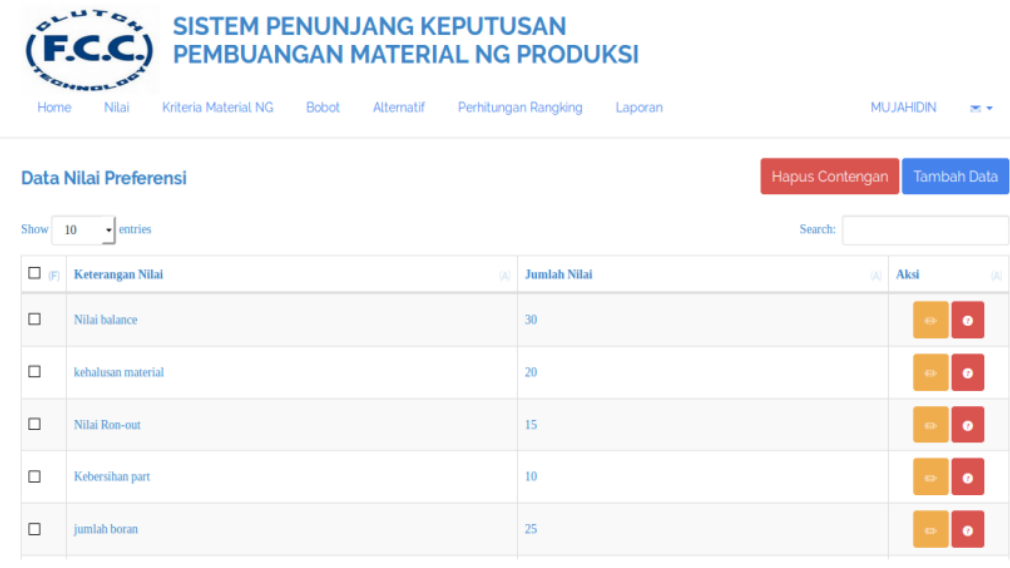

Gambar 7. Tampilan Input Nilai untuk Perhitungan Rangking

\section{Kesimpulan dan Saran}

\subsection{Kesimpulan}

Dari hasil penelitian yang telah dilakukan dihasilkan beberapa kesimpulan, diantaranya :

a. Hasil akhir metode Weighted Product memiliki nilai akhir yang berubah sesusai banyaknya alternatif.

b. Sistem akan memilih dan menampilkan satu metarial NG yang akan dibuang ke limbah produksi NG yang statusnya tidak bisa di repair kembali.

c. Metode Weighted Product dapat digunakan dalam SPK untuk menentukan pembuangan material NG produksi.

\subsection{Saran}

Sistem pendukung keputusan dalam pembuangan material NG produksi berdasarkan syaratsyarat dari hasil penilaian, sehingga diperlukan beberapa variabel lain dalam metode WP agar hasil yang didapat bisa lebih akurat.

\section{Ucapan Terimakasih}

Kami ucapkan banyak terimakasih kepada STMIK Kharisma Karawang yang telah banyak memberikan bantuan berupa finansial dan pemikiran selama penelitian berlangsung. 
ILKOM Jurnal Ilmiah Volume 11 Nomor 1 April 2019

Terakreditasi peringkat 3 SK. No. 28/E/KPT/2019

\section{Daftar Pustaka}

[1] Reksohadiprojo., "Manajemen Industri," Graha, Semarang, 2008.

[2] Sutrisno., "Ilmu Ekonomi Menengah," Alika, Yogyakarta, 2001.

[3] Rani., "Sistem Pendukung Keputusan Pemilihan Sepeda Motor Dengan Metode Weighted Product,". Program Studi Ilmu Komputer, FMIPA Universitas Mulawarman, vol. 10, no. 2, 2013.

[4] Nurarifah, Syafitri., "Penerapan Metode Weighted Product dalam Sistem Penunjang Keputusan Pemilihan Laptop Berdasarkan Kebutuhan Spesifikasi Berbasis Web." Universitas Haluoleo Kendari, 2016.

[5] Fauziah Ayu., "Implementasi Metode Weighted Product (WP) Sistem Pendukung Keputusan Seleksi Calon Karyawan," Universitas Islam Negeri Maulan Malik Ibrahim Malang, 2016.

[6] Cahyono., "Penerapan Metode WP (Weigthed Product) Untuk Mahasiswa LulusanTerbaik," Teknik Informatika Universitas Muhamadiyah Purwokerto, vol. IV, no.1, 2016.

[7] Satzinger J., Jackson R., Burd S. "System Analysis and Design in a Changing World, fourth edition," Boston Course Techonogy, 2007. 